\title{
Corrigendum to "GK-1 Improves the Immune Response Induced by Bone Marrow Dendritic Cells Loaded with MAGE-AX in Mice with Melanoma"
}

\author{
Gabriela Piñón-Zárate, Miguel Ángel Herrera-Enríquez, Beatriz Hernández-Téllez, \\ Katia Jarquín-Yáñez, and Andrés Eliú Castell-Rodríguez
}

Laboratorio de Inmunoterapia e Ingeniería de Tejidos, Departamento de Biología Celular y Tisular, Facultad de Medicina, Universidad Nacional Autónoma de México Edificio A, Sexto Piso, Ciudad Universitaria, Avenida Universidad No. 3000, Ciudad de México 04510DF, Mexico

Correspondence should be addressed to Andrés Eliú Castell-Rodríguez; castell@unam.mx

Received 5 October 2015; Accepted 8 November 2015

Copyright (C) 2015 Gabriela Piñón-Zárate et al. This is an open access article distributed under the Creative Commons Attribution License, which permits unrestricted use, distribution, and reproduction in any medium, provided the original work is properly cited.

In the paper titled "GK-1 Improves the Immune Response Induced by Bone Marrow Dendritic Cells Loaded with MAGE-AX in Mice with Melanoma" [1] the phrase "Recently, it has been reported that subcutaneous administration of GK1 in mice with melanoma induces regression of the tumor mass and increases survival" should be as follows: "Recently, our group has shown that subcutaneous administration of GK-1 and DCs in mice with melanoma induces regression of the tumor mass and increases survival (unpublished data)."

\section{References}

[1] G. Piñón-Zárate, M. Á. Herrera-Enríquez, B. Hernández-Téllez, K. Jarquín-Yáñez, and A. E. Castell-Rodríguez, "GK-1 improves the immune response induced by bone marrow dendritic cells loaded with MAGE-AX in mice with melanoma," Journal of Immunology Research, vol. 2014, Article ID 158980, 12 pages, 2014. 


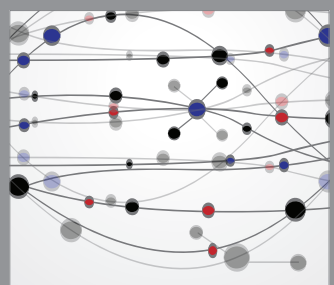

The Scientific World Journal
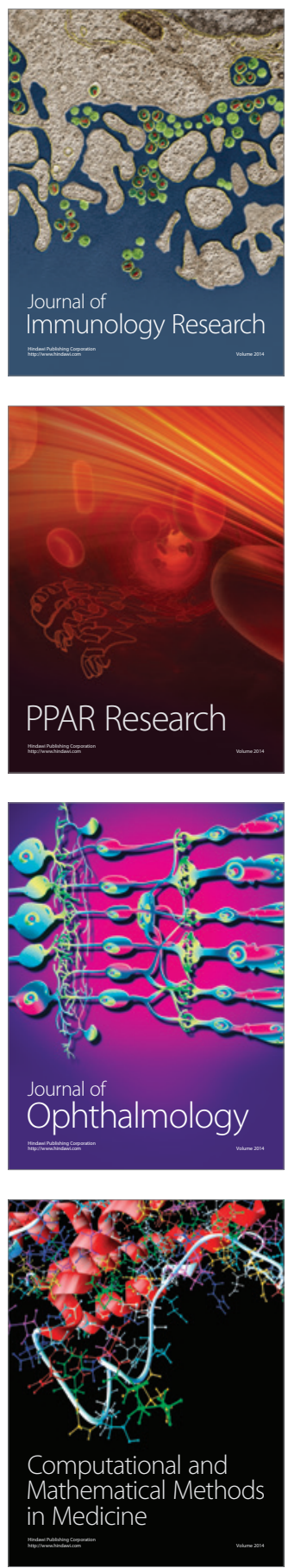

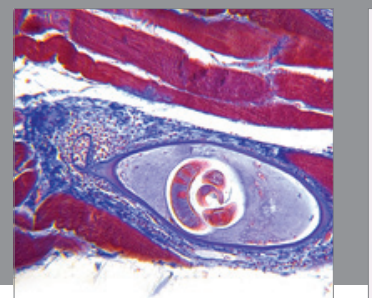

Gastroenterology

Research and Practice
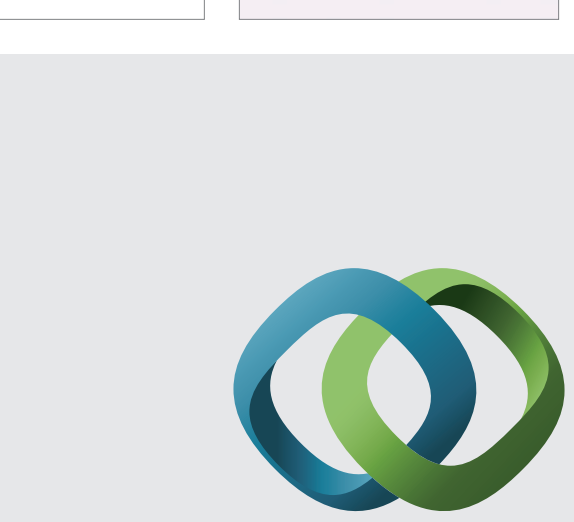

\section{Hindawi}

Submit your manuscripts at

http://www.hindawi.com
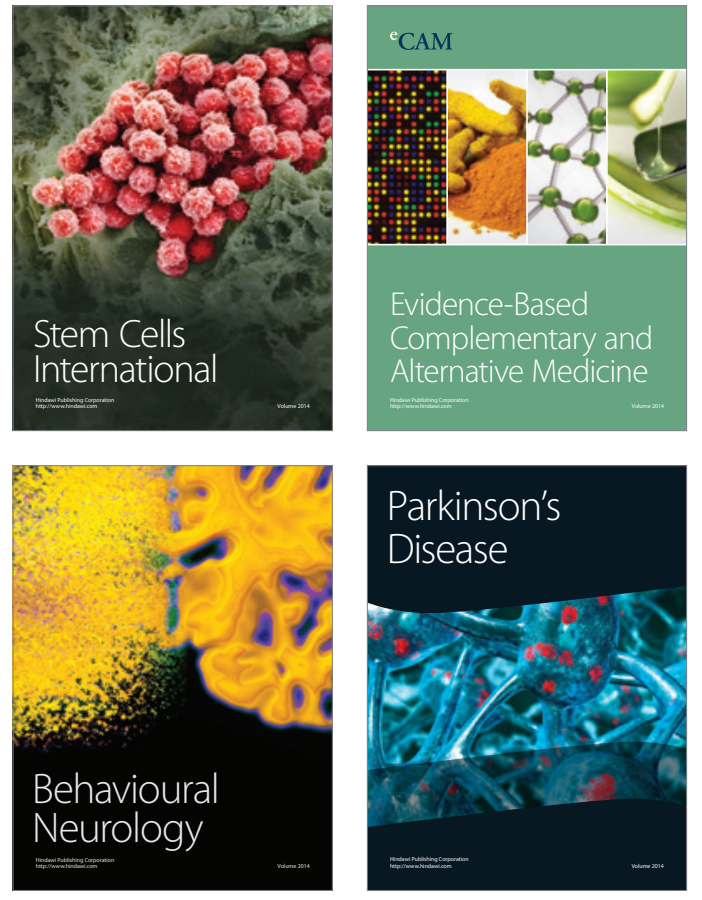
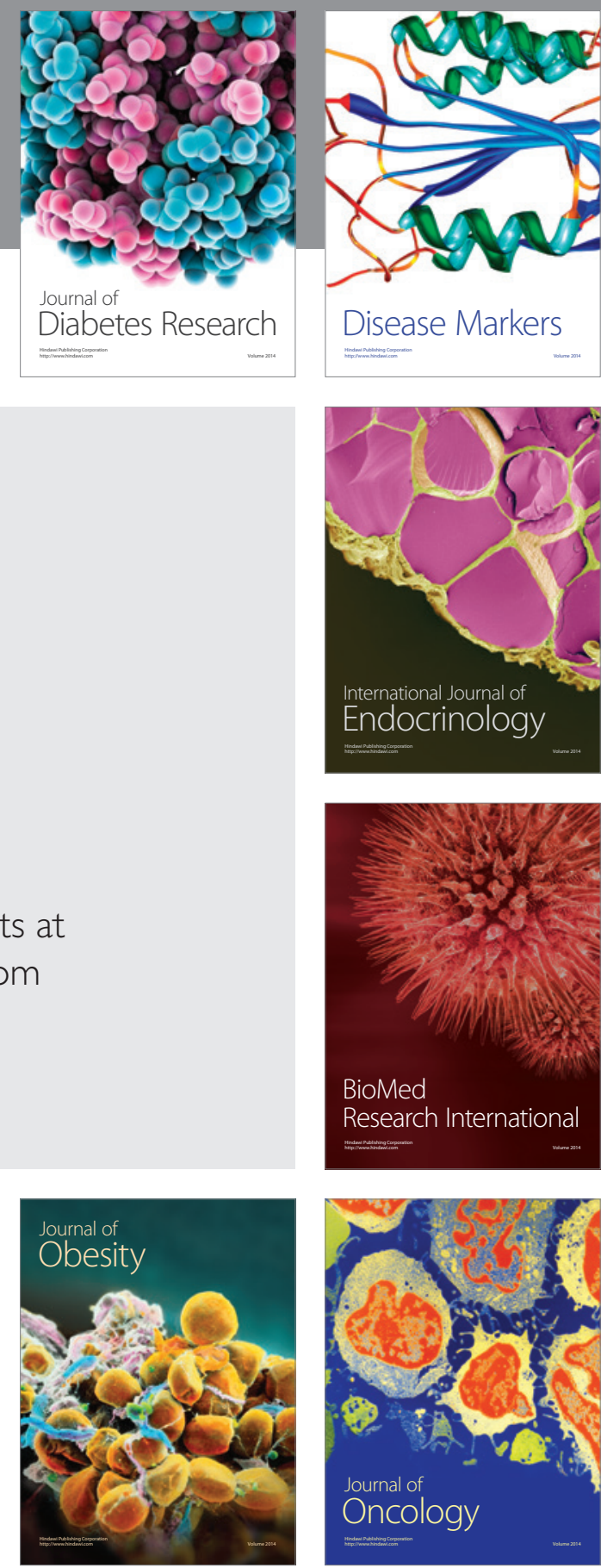

Disease Markers
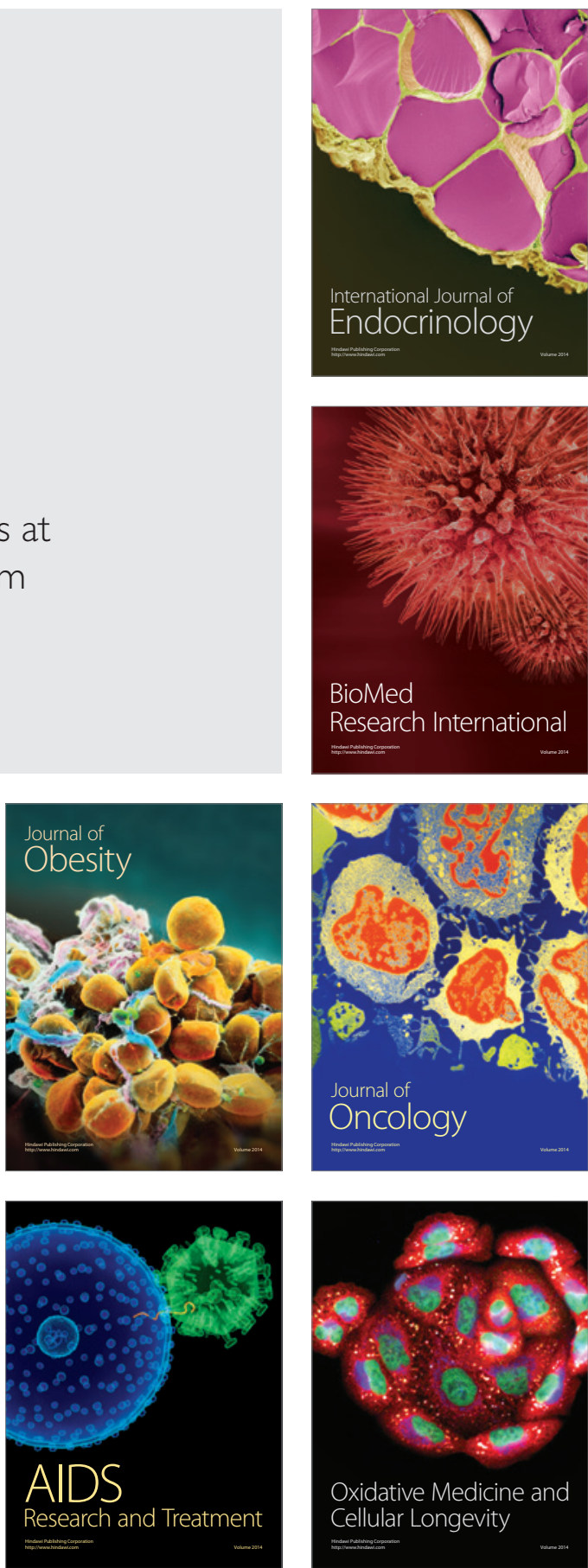